\title{
PEMANFAATAN TEPUNG ANAK AYAM (DOC) UNTUK MENSUBSTITUSI TEPUNG IKAN DALAM PAKAN IKAN BUDIDAYA
}

\author{
Kamaruddin*) dan Usman*) \\ *) Balai Riset Perikanan Budidaya Air Payau, Maros
}

\begin{abstract}
ABSTRAK
Salah satu alternatif yang dapat dilakukan untuk mengurangi penggunaan tepung ikan dalam industri pakan, adalah dengan penjajakan beberapa bahan baku lokal ataupun pemanfaatan beberapa jenis limbah industri seperti pemanfaatan limbah industri cold storage, pemotongan hewan, dan penetasan ayam. Telah dilakukan beberapa kegiatan uji kecernaan dan pemanfaatan limbah tersebut dan menunjukkan hasil yang signifikan dalam mensubstitusi tepung ikan dalam pakan ikan. Meskipun bahan dari jenis limbah ini masih dalam bentuk utuh, sehingga masih perlu diolah sampai menjadi bahan baku yang siap untuk diramu dengan bahan baku lainnya. Seperti halnya dengan pemanfaatan limbah DOC dalam pakan ikan, yang harus melalui beberapa proses seperti pembakaran, pengukusan, penjemuran, penepungan kasar, dan penepungan halus. Sehingga melalui proses tersebut dari penelitian yang dilakukan diperoleh rendemen sekitar 21,4\% Dari hasil analisis proksimat DOC ini didapatkan protein kasar 59,2\% lemak kasar 13,2\% kadar abu 7,9\% serat kasar 1,2\% dan BETN 18,2\% Hasil uji kecernaan tepung DOC pada ikan kerapu macan adalah kecernaan bahan kering sekitar $88,2 \%$ kecernaan protein sekitar $73,7 \%$ dan kecernaan lemak sekitar $70 \%$
\end{abstract}

KATA KUNCI: manfaat DOC, dalam usaha budidaya

\section{PENDAHULUAN}

Dalam budidaya ikan, pakan merupakan komponen biaya yang cukup mahal hingga mencapai $60 \%-70 \%$ dari biaya operasional. Hal ini disebabkan tingginya harga bahan baku pakan yang sebagian besar diimpor. Salah satu alternatif yang biasa dilakukan untuk menurunkan harga pakan adalah mengurangi atau mengganti bahan baku impor dengan bahan baku lokal yang potensial sebagai bahan substitusi antara lain tepung ikan rucah, kepala udang, bungkil kelapa sawit, dedak, ataupun bahan limbah seperti darah hewan ternak. Di samping itu, ketersediaan bahan-bahan tersebut cukup memadai, harganya pun relatif murah (Ahmad et al., 2000).

Bahan pakan yang berbasis laut khususnya tepung ikan memiliki peranan sangat penting sebagai sumber protein dalam pakan. Hal ini disebabkan tepung ikan mengandung protein yang tinggi dengan komposisi dan kadar asam amino esensial yang lengkap serta kandungan faktor anti nutrisinya sedikit (Allan et al., 2000). Di Indonesia diprediksikan pada tahun 2005 kebutuhan tepung ikan untuk kegiatan peternakan dan perikanan sekitar 303 ribu ton dan sebagian besar di antaranya harus diimpor (Nikijuluw, 1998; Sukadi et al., 1999).

\section{POTENSI BAHAN BAKU ANAK AYAM}

Di Kabupaten Maros terdapat dua industri penetasan ayam dengan frekuensi produksi masing-masing 5 kali seminggu. Anak ayam yang mati atau dimatikan pada setiap produksi rata-rata 2.000 ekor, sehingga total perbulannya adalah 2.000 ekor $\times 5$ atau 10.000 ekor/bulan/ industri atau 20.000 ekor/bulan. Apabila anak ayam berbobot 413,1 g maka total diperoleh $8.262 \mathrm{~kg}$ anak ayam. Untuk menentukan rendemen anak ayam tersebut, dilakukan percobaan dari 10 ekor anak ayam dengan bobot awal rata-rata 413,1 g, untuk dibakar hingga bobotnya berubah menjadi $376,0 \mathrm{~g}(91,1 \%$ ). Kemudian dikukus hingga bobot menjadi $259,5 \mathrm{~g}(62,8 \%$, dan setelah dikeringkan (tepungkan) sisa bobotnya adalah 88,7 g $(21,5 \%)$. Berdasarkan uji tersebut nilai rendemen pengolahan tepung anak ayam ditentukan sekitar $21,5 \%$ Melalui perhitungan ini yaitu: bobot total produksi/bulan $x$ besarnya rendemennya diperoleh nilai: $8.262 \mathrm{~kg} \times 21,5 \%$ $=1.776,4 \mathrm{~kg}$ tepung anak ayam per bulan. Tepung anak ayam ini akan dicobakan untuk mensubstitusi tepung ikan dalam pakan pembesaran kepiting.

\section{CARA MEMPRODUKSI TEPUNG ANAK AYAM}

Pengolahan tepung dari anak ayam cacat dan mati pada saat penetasan (DOC) atau sengaja dimatikan oleh pemilik penetasan dengan alasan jantan atau cacat. Proses pengolahannya adalah sebagai berikut: 


\section{Pembakaran}

Anak ayam yang diperoleh dari tempat penetasan dalam keadaan mati, dibakar dengan menggunakan kompor minyak tanah. Tujuan pembakaran adalah untuk menghilangkan bulu (Gambar 1a dan 1b), lama pembakaran tergantung dari hilangnya/terbakarnya semua bulu anak ayam. Selama proses pembakaran terjadi kantong kuning telur pecah, sehingga isi menetes kebawah, kulit anak ayam terkelupas dan kelihatan gosong. Proses selanjutnya adalah dikukus dan dikeringkan.

\section{Pengukusan}

Lama pengukusan \pm 15 menit pada suhu $100^{\circ} \mathrm{C}$. Tujuan pengukusan adalah untuk menghilangkan sebagian sisa bulu yang masih melengket pada kulit anak ayam, dan agar cairan kuning telur menggumpal sehingga bisa ditepungkan, serta untuk memudahkan dalam proses pengeringan (Gambar 2a dan 2b). Dalam proses pengukusan ini terlihat adanya perubahan bentuk dan warna anak ayam, tulang lebih mudah patah, dan untuk mengurangi kadar airnya. Untuk menghindari pembusukan sebaiknya dimasukkan kedalam freezer (pendingin) baru keesokan harinya dicincang atau digiling dengan menggunakan gilingan daging.

\section{Penggilingan}

Anak ayam yang baru dikeluarkan dari freezer biasanya membeku, sebaiknya dipotong-potong kecil lalu digiling (Gambar 3a dan 3b). Masukkan sedikit demi sedikit kedalam mesin penggiling agar tidak terjadi penyumbatan pada mesin penggiling.

\section{Penjemuran}

Anak ayam yang telah digiling selanjutnya dijemur di bawah sinar matahari dengan menggunakan para-para yang terbuat dari waring hijau, agar supaya sisa air yang ada dalam daging bisa tiris. Apabila cuaca tidak memungkinkan, maka pengeringan bisa digunakan oven, dengan suhu tidak lebih dari $60^{\circ} \mathrm{C}$ untuk menghindari kerusakan asam amino dan asam lemak. Selama penjemuran diaduk setiap dua jam untuk mempercepat proses pengeringan (Gambar 4a dan 4b). Setelah kering siap untuk dibuat tepung.

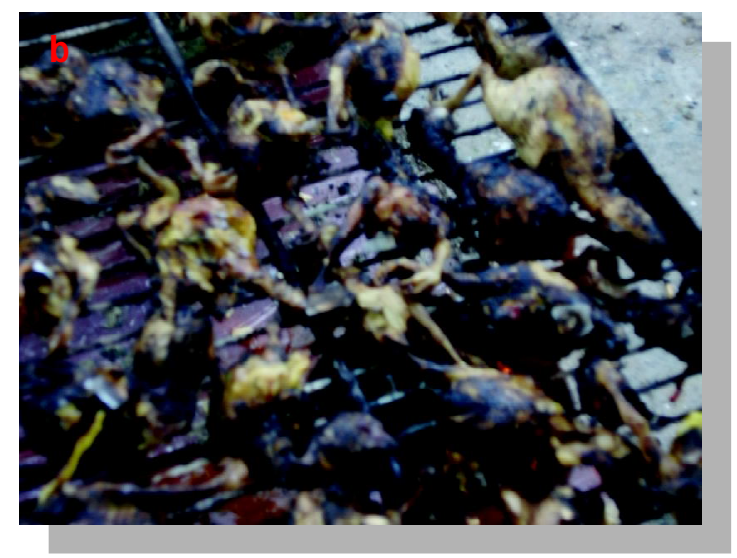

Gambar 1. Anak ayam sebelum dibakar (a), anak ayam sedang dibakar (b)
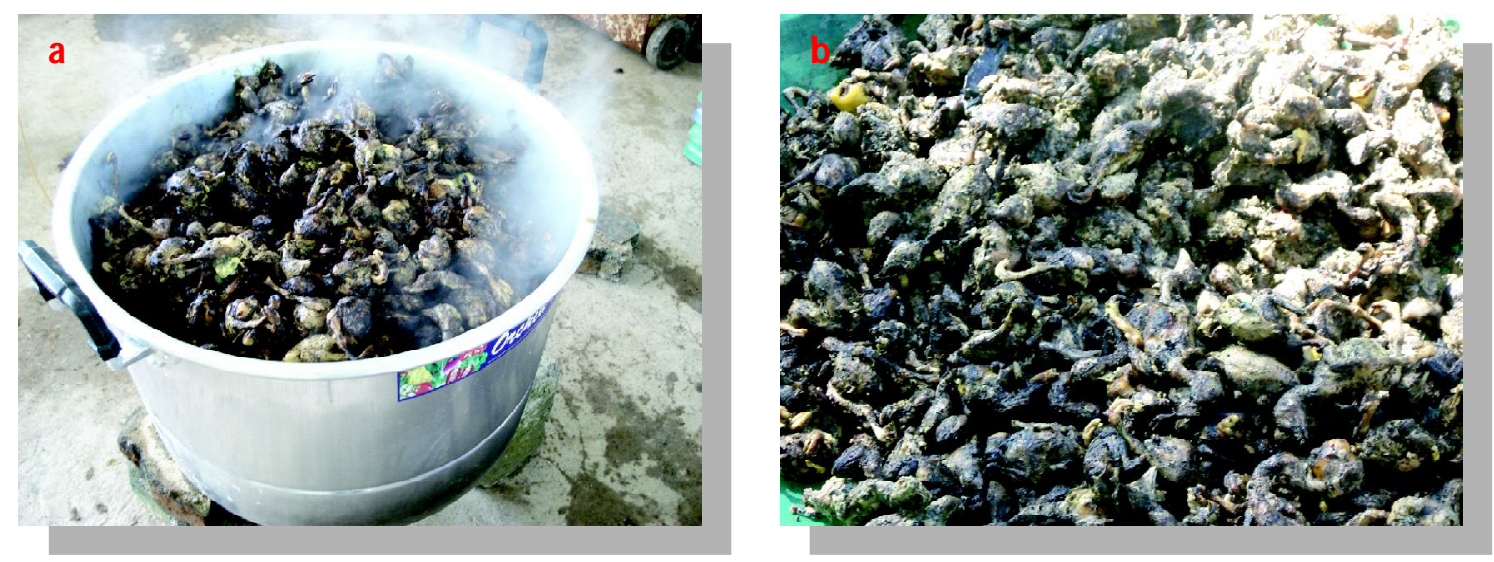

Gambar 2. Anak ayam sedang dikukus (a), anak ayam setelah dikukus (b) 

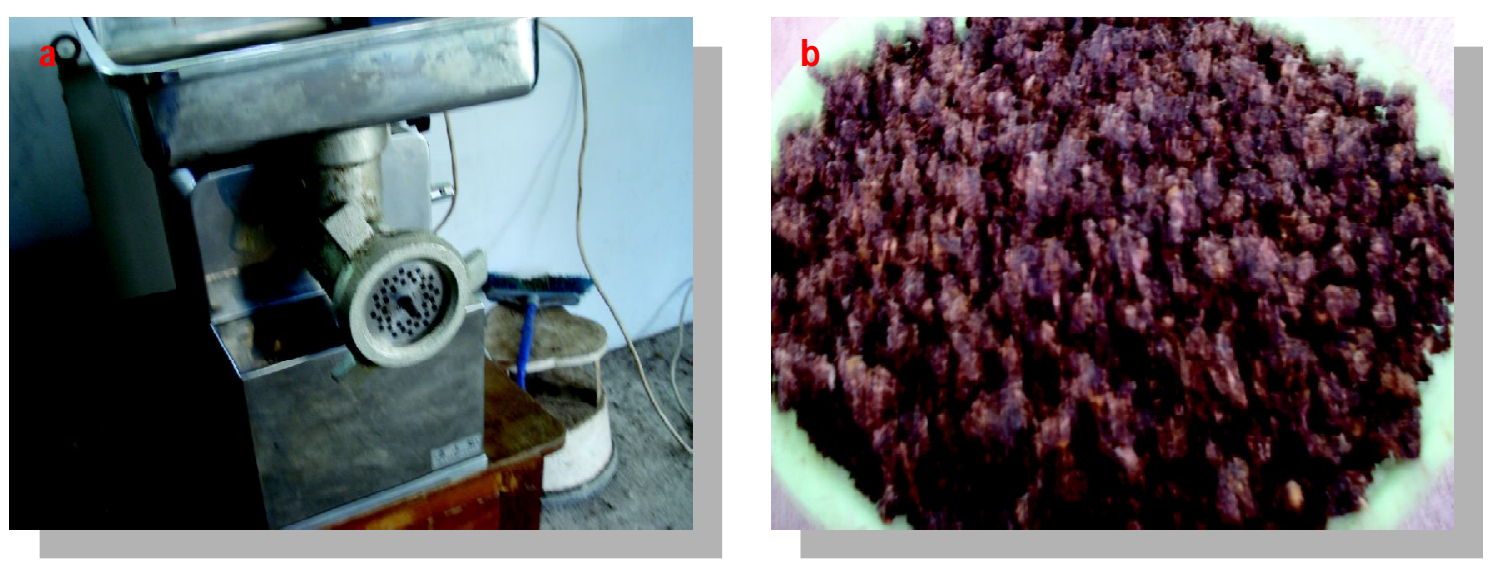

Gambar 3. Mesin penggiling (a), anak ayam telah digiling (b)
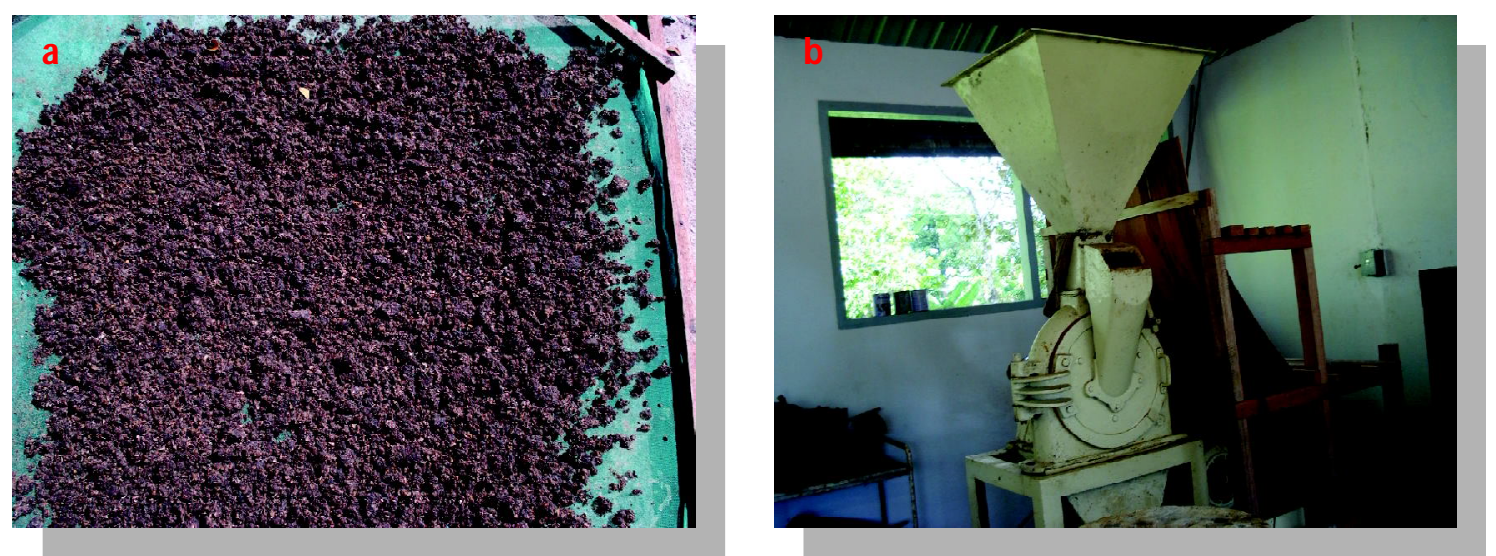

Gambar 4. Anak ayam giling sedang dijemur (a), mesin penepung (b)

\section{Penepungan}

Dalam pembuatan pakan sebaiknya komponen pakan harus halus sehingga dapat bercampur secara homogen pada semua bahan dan dapat menghasilkan pelet yang betul-betul padat. Proses penepungan anak ayam giling dilakukan dua tahap, pertama menggunakan saringan kasar dengan diameter $2 \mathrm{~mm}$, dan tahap kedua menggunakan saringan halus yang berdiameter $0,5 \mathrm{~mm}$; selanjutnya tepung dikemas/bungkus dan disimpan pada tempat dingin.

\section{PEMANFAATAN TEPUNG DOC}

Sesuai dengan prosedur dalam membuat formulasi pakan, maka semua jenis bahan baku kasarnya terlebih dahulu dianalisis nutrisi masing-masing bahan. Hasil analisis proksimat tepung anak ayam, adalah: protein $59,27 \%$ lemak $13,27 \%$ abu $7,95 \%$ serat kasar $1,26 \%$ BETN 18,25\% Kamaruddin \& Usman (2006) telah melakukan penelitian uji kecernaan tepung DOC pada ikan kerapu macan di keramba jaring apung, dari kegiatan tersebut diperoleh kecernaan bahan kering sekitar $88,2 \%$ kecernaan protein sekitar 73,7\% dan kecernaan lemak sekitar $70 \%$ Hasil tersebut menunjukkan bahwa tepung DOC berpeluang dapat dimanfaatkan untuk mengurangi penggunaan tepung ikan sebagai sumber protein dalam pakan ikan kerapu macan.

Kabangnga et al. (2005) melaporkan bahwa penambahan tepung DOC 37,5\% dalam pakan kepiting bakau dapat memberikan pertumbuhan dan pertambahan lebar karapas yang tidak berbeda nyata dengan kontrol (tanpa penambahan tepung $\mathrm{DOC}$ ), ini berarti dengan pemanfaatan tepung DOC dapat mengurangi penggunaan tepung ikan pada pakan kepiting bakau sebanyak 37,5\% Hal ini disebabkan karena pada anak ayam masih banyak kuning telurnya sehingga asam amino tepung DOC hampir sama dengan kandungan asam amino tepung ikan (Tabel 1).

Penelitian pakan buatan terhadap larva dan pembesaran kepiting bakau yang menggunakan bahan baku lokal sebagai sumber protein masih sangat kurang, sementara bahan baku lokal sebagai sumber protein tersedia cukup banyak dan relatif murah (Hutabara, 1999). Salah satu bahan baku lokal yang dapat digunakan sebagai sumber protein 
Tabel 1. Komposisi asam amino tepung ikan dan tepung DOC

\begin{tabular}{lccc}
\hline \multirow{2}{*}{ Asam amino } & Kode & \multicolumn{2}{c}{ Kandungan (\%) } \\
\cline { 3 - 4 } & & Tepung ikan & Tepung D OC \\
\hline Aspartat & ASP & 5,105 & 4,768 \\
Threonin & THR & 2,430 & 2,361 \\
Serin & SER & 2,034 & 2,379 \\
Glutamat & GLU & 8,722 & 9,368 \\
Glysin & GLY & 3,391 & 5,227 \\
Alanin & ALA & 3,382 & 3,891 \\
Cystein & CYS & 0,516 & 0,187 \\
Valin & VAL & 2,584 & 3,081 \\
Methionin & MET & 1,495 & 0,062 \\
Isoleusin & ILE & 2,208 & 2,405 \\
Leusin & LEU & 4,004 & 4,260 \\
Tyrosin & TYR & 1,796 & 1,639 \\
Phenilalanin & PHE & 2,485 & 1,965 \\
Hydroksi-Lysin & HYLYS & 0,137 & 0,515 \\
Lysin & LYS & 4,222 & 3,889 \\
Histidin & HIS & 1,524 & 1,212 \\
Arginin & ARG & 3,064 & 4,058 \\
Hydroksi-Prolin & HYPRO & 0,591 & 1,376 \\
Prolin & PRO & 2,106 & 3,620 \\
\hline \multicolumn{2}{c}{ Jumlah (Protein) } & $\mathbf{5 1 , 7 9 5}$ & $\mathbf{5 6 , 2 8 1}$ \\
\hline
\end{tabular}

') Metode analisis : HPLC khusus deteksi Ninhydrin postcolumn-reaction ') Alat : High Speed Amino Acid Analyzer-Hitachi Model 835 Sumber: Kabangnga et al. (2005)

pakan kepiting bakau adalah limbah peternakan ayam. Limbah ini mengandung protein cukup tinggi yaitu sekitar 59\%(Hartadi et al., 1993) dan belum dimanfaatkan secara optimal di beberapa daerah, khususnya luar Pulau Jawa. Selain itu, limbah ini juga mengandung kadar lemak yang cukup tinggi 20\%-25\%dengan komponen utama berupa asam lemak jenuh dan kolesterol.

\section{KESIMPULAN}

Tepung DOC sangat memungkinkan untuk dijadikan bahan substitusi tepung ikan dalam pembuatan pakan ikan karena ketersediaannya cukup besar dan berkesinambungan. Selain itu, kandungan nutrisinya juga cukup tinggi dengan kandungan asam amino hampir sama dengan tepung ikan.

\section{DAFTAR PUSTAKA}

Ahmad, T., Rachmansyah, and N.N. Palinggi. 2000. The availability and use of fish feed local ingredients for humpback grouper grow-out. Proceeding of Regional Workshop on Managemen Strategies for Sustainable Sea Farming and grouper. Aquaculture. NACA, Bangkok, Thailand. p. 90-120.

Allan, L.G., S. Parkinson, M.A. Booth, D.A.J. Frances, and Waner-Smith, $R$. 2000. Replacement of fish in diets for Australian silver perch, Bidyanusbidyanus: I. Digestibility of alternative ingredients. Aquaculture. 186: 293310.

Hartadi, H., S. Reksohadiprojo, dan D.T. Allen. 1993. Tabel Komposisi Pakan untuk Indonesia. Gadjah Mada University Press. Yogyakarta. 145 pp.

Hutabara, J. 1999. Suitability of lokal raw materials for mud crab feed development. In mud crab aquaculture and biology. ACIAR Proceedings No. 78. Canberra. 216 pp.

Kabangnga, N., N.N. Palinggi, Usman, dan Kamaruddin. 2005. Subtitusi tepung ikan dengan tepung DOC pada pakan pembesaran kepiting bakau di keramba jaring apung. Laporan Hasil pada Balai Riset Perikanan Budidaya Air Payau Maros. 12 pp.

Kamaruddin dan Usman. 2006. Uji kecernaan beberapa bahan pada ikan kerapu macan di keramba jaring apung. Laporan Hasil Penelitian pada Balai Riset Perikanan Budidaya Air Payau Maros. 10 pp.

Nikijuluw, V.P.H. 1998. Analisa Kebijakan Pengembangan Industri Tepung Ikan di Indonesia. Pusat Penelitian Sosial Ekonomi Pertanian. Badan Penelitian dan Pengembangan Pertanian. 43 pp.

Sukadi, F., O. Praseno, dan H.E. Irianto. 1999. Dukungan litbang perikanan terhadap kinerja dan keberhasilan Gema Proteina 2001. Warta Penelitian Perikanan Indonesia. 5(2): 2-8. 